\title{
El álbum familiar y su migración digital
}

\author{
Recibido: 10 de febrero de 2014 \\ Aceptado: 11 de agosto de 2014 \\ Publicado: 28 de noviembre de 2014
}

\author{
Mercedes Sarapura Sarapura \\ mercedicosas@gmail.com \\ Lourdes Peschiera Chanamé \\ lpeschiera4@gmail.com
}

Universidad de San Martín de Porres (Perú)

Resumen: El presente trabajo se aplica al análisis del álbum familiar como objeto cultural y su progresivo desplazamiento a la versión digital, con el fin de procurar un acercamiento a los microescenarios donde tienen lugar los aconteceres cotidianos de los individuos y en los que se gesta la comunicación interpersonal con los condicionamientos tecnológicos actuales; la misma que se ve reflejada en el álbum, cual archivo de sus imaginarios y vivencias. Conocer de cerca sus entornos (ya mediatizados, relacionados con lo que ocurre a la gente y sus vivencias) hace posible una profunda comprensión de la comunicación a nivel social con toda la complejidad que supone la incursión de la tecnología en los espacios privados. Así, el álbum familiar se convierte en elemento clave, donde converge lo tradicional con lo moderno. Lo tradicional en tanto que, como vértice cultural, evoca la identidad, la memoria y la muerte. Lo moderno, porque como canal y mensaje comunicativo está sujeto a los cambios producidos por el avance tecnológico que condiciona la calidad del proceso comunicativo, que a su vez tendrá un efecto en los estilos de vida y la cultura de la gente. En suma, esta mirada es también oportuna para definir el rol de la fotografía al interior de la célula de una sociedad en la que la imagen tiene un papel predominante.

Palabras clave: Álbum familiar, comunicación, fotografía, álbum digital.

Abstract: The following article is related to the analysis of the family album as a cultural
element and its progressive transition to the digital version aimed at approaching to
the micro-scenarios where take place the daily events of the individuals and is born the
interpersonal communication with current technological constraints. This communication
is also reflected in the album like the archives of the individual mindsets and experiences.
Learning more about their contexts, -most of them like archetypes-, what occurs to the
persons and their experiences makes it possible to deeply understand communication on 
the social level taking into account the complexity that involves the irruption of technology inside the private spaces, becoming the family album the key element where tradition and modernity converge. Tradition, considered as the cultural apex, evokes the identity, memories and death whilst modernity involves a channel and a communicative message subject to changes caused by the technological advance, conditioning the quality of the communicative process as well as having an effect on the lifestyle and culture of the people. In sum, this approach is also appropriate to define the function of photography inside the cell of a society where images play a prominent role.

Key words: Family Album, Communication, Photography, Digital Album.

\section{Introducción}

La tecnología no sólo ha cambiado la comunicación a distancia (haciéndola constante y accesible, habiendo conseguido con eso debilitar considerablemente el determinismo que antes suponían las lejanías), sino que también ha suprimido las fronteras del tiempo con los diferentes mecanismos que permiten hoy (en cualquier lugar y momento) registrar lo que ocurre y multiplicarlo por cientos de veces. Con esto, pareciera que el pasado dejara de existir: no ya por el olvido, sino por persistir y hacerse una y otra vez presente a través de las fotografías y vídeos.

De hecho, se podría inferir que esta es la era en lo que todo es presente. Un presente que se encuentra anegado de pasados inmediatos y donde el pasado remoto ha perdido el valor significativo que en otras épocas tenía. "El uso social que se le ha dado a este invento lo hace ahora masivo en toda su extensión, dejando muy de lado lo artístico, pero incluyendo para su uso cotidiano cánones muy claros sobre lo fotográfico. La experiencia, dice Sontag, se ha visto reducida a imágenes, siendo más importante dejar el testimonio en la cámara que vivirlo verdaderamente [...] el recuerdo es más importante que la misma experiencia" (Morales, 2003: 27).

Así pues, el gran salto tecnológico ha ocasionado no sólo nuevos estilos de vida, sino nuevas formas de relatar las vivencias, de vivir los recuerdos y de guardar memoria de los acontecimientos. El rol social de la fotografía no sólo pasa por lo masivo y extraordinario, sino también por lo familiar y cotidiano. En primera instancia, la vida cotidiana (dentro del ámbito familiar) se vio favorecida por el avance tecnológico, ya que antes la fotografía era requerida para acontecimientos especiales. No obstante, con el tiempo, el lente fotográfico (por su accesibilidad) llegó a tener la capacidad de convertir en acontecimiento todo aquello que a los ojos humanos resultaba interesante (incluso lo más grotesco, cruel o insignificante), debido a la tendencia estetizante de la fotografía, tal como afirma Sontag (2006: 125), quien además sostiene que "nadie jamás descubrió la fealdad por medio de las fotografías. Pero muchos por medio de las fotografías han descubierto la belleza". La autora destaca que el nombre con que Fox Talbot patentó la fotografía (1841) fue "calotipo", del griego Kalos ("bello"). 
Sin embargo, también es verdad que (ahora más que nunca) el asombro por el acontecimiento, mostrado en la foto, disminuya por saturación o se experimente de forma diferente. "Las fotografías crean lo bello y -tras generaciones de hacer fotografías- lo desgastan. Algunos esplendores de la naturaleza, por ejemplo, se han abandonado del todo a las infatigables atenciones de los entusiastas aficionados a la cámara. A los saciados de imágenes es probable que las puestas de sol les parezcan sensibleras; se parecen ya demasiado [...] a fotografías" (ibídem: 126).

Esta saturación fotográfica, de lo natural o urbano, se repite en el ámbito familiar; máxime, en la actualidad. Antiguamente, en la fotografía familiar, el hallazgo de lo bello giraba en torno a los momentos especiales compartidos entre sus miembros o en la belleza propia de estos, que quedaba retratada en la sesión fotográfica. En cambio, en la actualidad, cualquier circunstancia irrelevante puede ser lugar de lo bello, pero también de lo gracioso y lo anecdótico, ya que en la fotografía familiar lo bello se circunscribe estrechamente a lo emocional y documental.

En nuestros días, sucede que la considerable cantidad de fotos anecdóticas disminuye el carácter testimonial de las mismas, debido a que lo anecdótico (que guarda la intensidad de lo efímero) pronto se pierde $y$, con él, el valor significativo del pasado remoto o de lo ocurrido hace mucho tiempo. Estas son algunas de las transformaciones acaecidas en el registro fotográfico familiar a partir de la llegada de lo digital y que, de igual modo, ha alterado sus formas de organización y archivo.

El álbum familiar (como soporte de fotografías que remiten no sólo a la estética, sino a la historia de una comunidad, a su pasado y memoria) evoca también la identidad. La vigencia del álbum fotográfico quedará siempre sujeta a la imperativa necesidad humana de vencer a la muerte y anular el olvido (a través de las imágenes) y la de definir y conservar su identidad con ellas.

Warner (2012: 6) observa que "antes de materializarse en una cámara y una lente, la fotografía fue una idea. El deseo de realizar una clase especial de representación, originada en el propio objeto, es tan antigua como la humanidad". Los primeros hombres, en las remotas cuevas de Altamira, trazaron en sus pedregosas entrañas (no sin violencia) el rojo púrpura de sus lides y la caza para sobrevivir: todos estos momentos que trascendieron al infinito, a través de un poderoso eco de siluetas y formas. Con esa misma inquietud el hombre posmoderno (con el raudo reflejo de un as de luz y el mismo esmero) busca dejar constancia de cuánto vive y de cuánto en el mundo encuentra de significativo. Dejar constancia de un presente (que se diluye entre las ranuras tupidas de los segundos y de sus microdesplazamientos) ha sido siempre el propósito: sobrevivir más allá del tiempo y de la muerte. En el principio era la Palabra, dice San Juan al comienzo de su Evangelio; y también es verdad que antes de la escritura era la imagen: la necesidad de reflejar, como en las aguas de las lagunas, la imagen de cuánto vivían.

¿Por qué ha sido, desde siempre, tan importante la imagen? La representación es clave desde el principio como elemento que robaba el ánima a su referente o cobraba existencia propia. 
Debray (1994: 20) observa que "es una constante trivial que el arte nace funerario, y renace inmediatamente muerto, bajo el aguijón de la muerte. Los honores de la tumba relanzan de un sitio a otro la imaginación plástica, la sepultura de los grandes fueron nuestros primeros museos y los difuntos nuestros primeros coleccionistas, pues esos tesoros de armas y vajilla, vasos, diademas, cofrecillos de oro, bustos de mármol, muebles de maderas preciosas, no se ofrecían a la mirada de los vivos"; y que a su vez estas representaciones suponían una existencia capaz de alterar o influir en sus vidas. "Un emperador chino pidió un día al primer pintor de su corte que borrara la cascada que había pintado al fresco en la pared del palacio porque el ruido del agua le impedía dormir [...] Así, el hombre racional del siglo $\mathrm{XV}$ todavía creía en sus imágenes para entenderlas. El agua pintada, que molestaba al chino, sosegaba al toscano. En los dos casos, una presencia atraviesa a la representación; la frescura de la onda contemplada para el cuerpo contemplativo" (ibídem: 13).

En la actualidad, ha cambiado esa capacidad que el hombre de otros siglos tenía para no sólo ver en las representaciones icónicas, sino también sentir, oír, oler, al otorgarle a dicha representación un aura que la divinizaba. Ha cambiado, más no ha desaparecido, ya que "si nuestras imágenes nos dominan, si por naturaleza pueden provocar algo distinto a una simple percepción, su capacidad -aura, prestigio o irradiación- cambia con el tiempo" (ibídem: 15) y lo crucial vendría a ser, a decir de Debray, entender ese poder que tiene la mirada puesta sobre dichas representaciones, que a su vez produce dichos cambios en la capacidad de provocar algo más que una percepción a través del tiempo.

Así pues, la historia de la mirada sobre las representaciones explica los códigos invisibles de lo visible que definen una cultura (ibídem). Entre esos códigos invisibles, al interior del álbum familiar, figura la voz, a pesar de permanecer en una sociedad dominada por la imagen, pero en la que la imagen carece del aura que en otros siglos se le daba.

\section{La fotografía como relato}

El álbum familiar es una forma de narrar la vida, aún en la cultura actual (anclada en los bastiones de la tecnología), ya que el relato sigue siendo importante como "elemento primordial del funcionamiento de la vida y de la creatividad del grupo", tal como sostiene Martín-Barbero (1989: 210), para quien sólo hay comunicación en la medida en que se asume la cultura de la gente, es decir, aquello "por donde pasa lo religioso, lo sexual, lo poético, el dolor, la emoción, la devoción" (ibídem). Uno de los objetos culturales a través de los cuales pasa todo lo mencionado por el autor es el álbum familiar: compendio de fotografías relacionadas con la vida individual y de grupo, que demanda una voz que cuente y describa los lugares, los calendarios, las costumbres, rituales, creencias, viejos personajes e ilusiones propias de una comunidad.

Para alcanzar un nivel significativo de comprensión de cómo se está dando la comunicación en la sociedad actual (con todos los cambios y nuevas tramas que ha impuesto la incursión de la tecnología en la vida privada de cada individuo), es preciso asomarse a sus circunstancias, al punto de realización de sus interacciones cotidianas donde se gesta la información y se 
da la comunicación, con el fin de conocer cómo ven, cómo sienten, cómo sufren y cuentan sus protagonistas, a decir de Martín-Barbero, aspectos que a su vez, quedan expuestos en estructuras como la del álbum familiar o el archivo fotográfico familiar.

Ahora bien, el centro del álbum familiar es la fotografía, cuya naturaleza que es la que la define. Difiere de otros sistemas de representación como la pintura, debido al referente. Barthes (1989: 136) lo explica de la siguiente manera: "Llamo 'referente fotográfico' no a la cosa facultativamente real a que remite una imagen o un signo, sino a la cosa necesariamente real que ha sido colocada ante el objetivo y sin la cual no habría fotografía". El autor sostiene que la pintura puede fingir la realidad sin haberla visto, ya que sus referentes son a menudo quimeras; mientras que nunca se puede negar en la fotografía que "la cosa haya estado allí". Con esto, Barthes deja en claro que hay una doble posición conjunta, de realidad y de pasado; y esta vendría a ser la esencia o el noema de la fotografía, cuyo nombre es "Esto ha sido" (ibídem). De tal modo que será fácil dilucidar por qué la fotografía pronto llegó a tener poderosa importancia en la vida de la gente, ya no sólo por la eficacia de su técnica, sino porque para llegar a obtenerla era preciso que sus elementos necesariamente hayan existido y estado frente a la cámara. Así, su carácter testimonial y realismo se hicieron muy relevantes.

Chambi (2014), desde la perspectiva del arte, sostiene que con la fotografía ocurre lo mismo que con la pintura, cuyo mayor interés (desde sus inicios) fue reflejar la realidad pero que luego devino en escuelas que distorsionaron la realidad o fueron más allá de ella como el surrealismo, el cubismo, etc. tal como Man Ray, quien trabajó la técnica surrealista y con ello sus obras estuvieron más en función del arte que de la realidad. No obstante, en la dimensión cotidiana y para el ciudadano de a pie, la fotografía se asoma más al "esto ha sido", que Barthes considera su esencia, ya que su poderosa facultad para capturar un fragmento de tiempo cobra enorme significación en cada historia personal, porque la defiende y sustenta; respalda al que narra su vida, le ayuda a dar testimonio y a fundamentar lo que ha vivido. Claro que los juegos y experimentos que se pueden hacer con las sofisticadas y modernas cámaras fotográficas hacen también posible que toda persona que lo busque vaya más allá de su realidad, aunque luego, no necesariamente, lo que realice sea arte.

El gesto de fotografiar los momentos de la vida tuvo arraigo entre los individuos desde que la cámara fotográfica se hizo más accesible en las sociedades del siglo XIX hasta la actualidad. Más allá del recuerdo que se busca preservar, la motivación es la de figurar y reafirmar el ego y la autoestima a partir de la exhibición. Para Badger (2009: 7 y 8) "la fotografía no es solo una forma artística en potencia, sino una de las formas artísticas más importantes de nuestro tiempo". El autor agrega: "Un recuerdo, naturalmente, puede ser tan insustancial y efímero como una sombra, pero hay otros tipos de recuerdos, algunos de los cuales, a diferencia de las sombras, son persistentes, obstinados y duraderos. Hay recuerdos buenos, recuerdos menos buenos, recuerdos reprimidos, recuerdos falsos, recuerdos compartidos, recuerdos raciales, recuerdos culturales. La fotografía está al servicio de todos, fotografiamos para consolidar nuestra visión del mundo, pero, en cuanto se activa el obturador, la imagen resultante solo revela un hecho pasado. Así, la imagen se convierte al instante en materia de un recuerdo. 
Sin embargo, la fotografía no es un recuerdo, sólo es la huella de un recuerdo. Y esa huella fotográfica genera la certeza de que algo existió, si bien es solo una representación de esa realidad y no la realidad en sí misma".

El álbum familiar es una articulación de fotografías que (reducidas a fotogramas en conjunto) narran una vivencia, como en el cine, aunque sin secuencia lógica. Dentro de él, la foto es una pequeña partícula significativa de lo que se ha vivido o de lo que ha sido y que unida a otras constituyen la estructura del recuerdo. Para Benjamin, "el valor cultural de la imagen [...] es el culto al recuerdo" (ápud Morales, 2003: 40). Comparada con la escritura, la foto puede ser una palabra con probabilidades de llegar a oración, al interior del álbum fotográfico.

El rol de la fotografía (a partir de su protagonismo en el núcleo social que es la familia) consiste precisamente en dar sentido a ese recuerdo otorgándole, a su vez, un lugar en el pasado entre las vicisitudes presentes de los vivos. Así, el álbum familiar (a través de un encadenamiento de fotografías) reconstruye ese pasado según la mirada del sujeto que lo organiza. Lo mismo ocurrirá posteriormente, de acuerdo con los relatos que sobre sus páginas abiertas reconstruyan una y otra vez las voces de sus propios protagonistas. La fotografía tiene potestad de trasladar al lugar de los hechos en sentido geográfico y temporal. "Es una máquina de tiempo, sobre todo en cuanto concierne a las personas. Una fotografía es capaz de ponernos en contacto visual con la fisonomía de alguien en la otra punta de la Tierra, o con un ser humano que ya no existe. La fotografía nos ha llevado a la luna y a los abismos del océano, y eso es sin duda una muestra de poderío [...] Nos pone en contacto inmediato con el pasado más lejano y remoto, con los vivos y con los muertos” (Badger, 2009: 8).

La fotografía, anexada dentro de un archivo o álbum, es el lugar en el que se entrecruzan dos dimensiones: la dimensión de la oralidad y la dimensión de la técnica. La foto en sí es símbolo de la modernidad, de la objetividad e incluso del más exhaustivo raciocinio; mientras que el discurso oral es propio de la subjetividad e imaginarios de la gente desde el hombre prehistórico. Armando Silva sostiene al respecto: "Las imágenes del mundo moderno, industrial al fin y al cabo, son hechas, principalmente, por medios mecánicos, o sea que dependen de un soporte distinto al mismo cuerpo humano que modifica y hace su expresión. Quizá por eso se asocie la foto en forma reiterada con la modernidad, pues de alguna manera se constituye en la técnica de la 'objetividad', quizá parangonando la verdad científica medible, o también la verdad de lo que está ocurriendo para los medios impresos de comunicación" (ápud Bayardo y Lacarrieu, 1999: 195). Empero, esa capacidad de trasmitir la más objetiva realidad (a través de un diario o periódico) es complementada por la escritura que suple el relato oral que, a su vez, es complemento de las imágenes fotográficas al interior de un álbum o de un archivo menos organizado que el de un álbum. "Sobre las fotos de caja podemos sentar la hipótesis de que la oralidad, su cuento literario, se sobrepone al código visual evidente de la fotografía y entonces este álbum posee la quintaesencia de todo álbum que termina siendo más para ser escuchado que visto" (ibídem: 187).

En esa interrelación entre oralidad y técnica (como conducto de objetividad de una realidad que se muestra), se puede evidenciar la preponderancia del relato que reconstruye 
los acontecimientos y, por ende, cuestiona esa objetividad que per se parece otorgar la fotografía. Fontcuberta cuestiona la objetividad de las fotos: sostiene que cada vez que se hace una fotografía, la imagen resultante no es "inocente", sino que parte de perspectivas ideológicas y culturales y que, además de ello, la actitud del receptor frente a la fotografía es diferente de la que tiene ante otro tipo de representaciones, pues de ella siempre tiene valores preconcebidos como que es objetiva, transparente, notaria de la historia, espejo con memoria, etc. (ápud Vidal, 2001). No obstante, observa también que en la actualidad la fotografía ya no posee el poder que tenía antes y que, más bien, la confianza ha pasado al operador humano, es decir, que ahora los observadores tienen más en cuenta que detrás de la lente fotográfica hay un ojo humano que observa todo desde una determinada perspectiva.

Asimismo, en el álbum (lugar donde mejor enhebran la imagen y la palabra), no hay un orden preestablecido ni en la organización de las fotos ni en el relato. El orden queda supeditado al azar. Hay quienes son más cronológicos, mientras que otros prefieren organizar sus recuerdos fotográficos según sus protagonistas o según acontecimientos especiales.

\subsection{El mensaje: lo que dicen las imágenes}

¿De qué hablan los álbumes? El mensaje en el álbum es fuente de reminiscencias de experiencias grupales, capaz de contener en imágenes el ciclo de vida de una familia, desde que se constituye hasta cuando los hijos se van o los padres fenecen. En todo caso, no se trata de un registro frío y cerebral, cual inventario de aconteceres que sólo sirve para señalar el tránsito de cada individuo por una época de la Historia. El eje fundamental (en torno al cual giran los momentos familiares importantes) es la felicidad, especialmente en el siglo pasado y en los inicios de la fotografía, cuando no era fácil acceder a ella y sólo se la tenía en momentos de especial importancia como bodas, bautizos, etc. La cotidianidad, motivación profundamente arraigada en los tiempos actuales, abre un abismo entre todo lo vivido con la fotografía hasta hace unas décadas atrás.

Ahora bien, además de las temáticas recurrentes que aborda la fotografía en el álbum familiar, Barthes (1989: 38) señala que la foto es objeto de tres prácticas o intenciones: el operator, que vendría a ser el fotógrafo; el spectrum el fotografiado; y el spectator, el que mira. A menudo, en la fotografía familiar suele ser el más olvidado el operator, el que toma la fotografía, que al principio era rol que asumía un fotógrafo contratado, ajeno a la vida familiar. Con el tiempo serían los padres, los hijos u otros parientes: ciertamente este papel ha quedado relegado al silencio, desconocimiento e indiferencia (a nadie le importa quién tomó la foto) de todos. Mientras que el spectrum (que significa "fantasma") es el centro de todas las atenciones. Más aún, spectrum, según observa el autor, tiene la misma raíz que el término "espectáculo", con lo cual el protagonista de la foto se constituye en parte de un espectáculo o en el espectáculo mismo. Incluso Barthes concluye que ese mismo término remite a "ese algo terrible que hay en toda fotografía: el retorno de lo muerto" (ibídem: 39), por lo que será menos difícil deducir que la fotografía alcanzaría su máxima expresión ahí cuando su referente ha desaparecido definitivamente. 
Por tanto, el spectrum es el mensaje que impacta en los ojos de quien lo mira desde un trozo de cartón, que vendría a ser el canal. La tercera práctica correspondería al spectator, quien se hace cargo de cotejar y examinar las fotos; el mismo que organiza las fotos en los álbumes y les da un orden, por lo que el álbum sería el resultado de dos influencias, la de las temáticas de las fotografías y la influencia del observador. A este punto, el spectator tiene un papel fundamental dentro del álbum fotográfico.

El fin de todo álbum es el de constituirse en archivo, más aún, en refugio de lo vivido al resguardo del olvido y la muerte. En suma, su fin es la conservación, pero también el de ser visto. Por lo que, el spectator tiene especial trascendencia en la interacción comunicativa que nace a partir del álbum familiar. El spectator es el tercero que mira y que, a su vez, da lugar a un cuarto personaje: el relatante o narrador, que suele ser el spectrum o alguien cercado al mismo.

Ciertamente, una fotografía es el resultado de diferentes aportes: el primero de ellos provendrá de la realidad en la que se configura el spectrum; luego será el operator, quien aportará el ángulo desde el que hará relevante dicha realidad; y finalmente por lo que sugiera el spectator y según lo que le informe el relatante. Ahora bien, en ese proceso comunicativo (en el que el relatante, el spectator y el spectrum interactúan y en el que la observación y la narración son decisivas) tendrá lugar el studium, "que no quiere decir, o por lo menos no inmediatamente, 'el estudio', sino la aplicación a una cosa, el gusto por alguien, una suerte de dedicación general, ciertamente afanosa, pero sin agudeza especial" (Barthes, 1989: 64).

El álbum y la fotografía despertarán el interés general y moderado de quien la mire. Sin embargo, como explica Barthes, existe la posibilidad de que en algún momento quede tocado por alguna de todas ellas, es decir, especialmente atraído hasta no poder nombrar lo que le atrae porque le produce una perturbación. El segundo elemento "que viene a perturbar el studium lo llamaré punctum; pues punctum es también: pinchazo, agujerito, pequeña mancha, pequeño corte y también casualidad. El punctum de una foto es ese azar que en ella me despunta (pero que también me lastima, me punza)" (ibídem: 65). Dicho punctum colocará a esa fotografía en un lugar preferencial entre todas las vistas por el observador.

Así pues, una foto puede comunicar muchas cosas: desde el pensamiento silencioso de sus protagonistas, hasta una involuntaria incongruencia a los ojos de su observador que, al llamarle poderosamente la atención, lo conmoverá y se constituirá en punctum. No hay una explicación lógica a este suceso, simplemente ocurre ante cualquier espectador, no necesariamente ligado a las fotos vistas y con cualquier foto, no necesariamente alguna especial o razonable.

Warner (2012: 6) señala que la idea de que "la fotografía es un tipo de copia única, ha fluctuado a lo largo de toda la historia del medio". Copia única de un segundo jamás recuperable de acuerdo con la capacidad de las cámaras fotográficas actuales; o, en los inicios de la técnica, de un largo periodo de tiempo en el que la pose era fundamental para 
conseguir la captura de la imagen. Así pues, aún cuando se trate de fotografías parecidas de la misma persona, en el mismo lugar y a la misma hora, nunca será el mismo instante, aunque sólo haya diferencia de un minuto pues de todas maneras se abrirá un abismo insalvable entre un instante y otro. En esa misma dirección tampoco hay dos relatos exactamente iguales sobre un mismo acontecimiento.

La fotografía conquista una diminuta fracción de tiempo y la eternidad. Un segundo y la perpetuidad se confrontan en ella y se hacen una sola cosa. Por tal, la foto es el escenario en el que tiene lugar el constante duelo entre lo que puede ser olvidado y la memoria, entre lo efímero y lo eterno; la vida y la muerte, en tanto que el ser mortal pervive en ella por siempre.

Barthes (1989) sostiene que la fotografía alcanza su máxima expresión cuando el referente desaparece, ya que para ella la presencia del referente es demandante, en tanto que si el objeto o alguien no ha estado ahí, no hay fotografía. Esto queda sumamente claro cuando el referente desaparece inexorablemente. No obstante, también es importante el sujeto que mira y contempla. En ese aspecto, comparte la misma condicionalidad con la escritura: un idioma escrito sólo será útil y de razonable existencia mientras haya quien pueda entenderlo. En el mundo hay cientos de lenguas perdidas, porque sus comunidades humanas se extinguieron. Así pues, todo mensaje se realiza en el entendimiento que obtiene de su emisor, pues parte del sentido del mensaje, el cual ha de permanecer pasivo en el ávido lector u observador. De lo contrario, se estaría frente al misterio: “¿Qué dirá?, ¿qué querrá decir con aquello?” o en el caso de la fotografía: “¿quiénes son?, ¿dónde están?, ¿qué hacen?", etc. En tal circunstancia, la fotografía familiar pasa a ser el registro documental de una familia en una determinada época, a costa de haber perdido la posibilidad de que alguien los identifique como conocidos y propios. A este punto, para el álbum familiar es fundamental el relato como puente y guía de información. Ese discurso oral que lo complementa y trasciende.

\subsection{Contextos de la fotografía}

La fotografía tiene un entorno que implican los elementos que rodean al protagonista, persona u objeto, que son parte del escenario que se contempla. Asimismo, consta de un contorno que es el cuadrado o el óvalo que limita el escenario fotografiado. En la fotografía impresa sería la forma del cartón que la contiene. Por último, el contexto o el conjunto de objetos: cartas, cabellos, hojas secas, tarjetas, etc. que rodean a la fotografía, así como otras dentro de un álbum o una caja. Todos ellos condicionan la lectura de la foto e influyen en ella.

Las fotografías de un álbum familiar cobran una significación muy diferente de las fotografías de un periódico. El proceso comunicativo es el mismo, pero la condición de los elementos son diferentes. En el caso del álbum familiar, el emisor y el receptor se conocen y tienen un vínculo de relación, si no estrecho, al menos cercano. El canal-soporte (el álbum) está acondicionado y armado de manera muy subjetiva, acorde con las elucubraciones internas de su dueño, mientras que el periódico tiene un diseño sobrio o demasiado encendido, de acuerdo con la intencionalidad y objetivos de la empresa periodística. Las fotografías son 
"propias" en el álbum familiar, mientras que en el diario son "impersonales" (aún cuando también podría haber algún grado de pertenencia si se trata de una vista de Machu Picchu, la esquina de una plaza conocida o la foto de un héroe nacional). La voz narrativa también es diferente: en el álbum es oral y doméstica, en tanto que se narra lo acontecido en el interior de una familia, escenario en el que todos son conocidos y próximos, mientras que en el periódico se da a través de la palabra escrita: en sus páginas todo es público e impersonal.

La fotografía periodística se propone ser objetiva y pretende esconder sus ribetes subjetivos con el fin de sugerir transparencia y cercanía a los hechos, aún cuando dicha intención no siempre se consigue; mientras que la fotografía familiar (aunque también busque ser objetiva y se presente como recurso testimonial de un hecho real) termina condicionada por la subjetividad o por la afectividad del relatante.

Factores como el contorno, el tamaño, la forma y la ubicación de la fotografía de un periódico tiene relevancia. Esto mismo se repite en la organización de las fotografías de un álbum familiar, aunque no con demasiada precisión, ya que los álbumes (más que confeccionados por un sujeto) los hace el tiempo y más de una mirada puede intervenir en ellos.

El color también es un carácter que condiciona el mensaje fotográfico. En los diarios o periódicos se sabe que las fotos a colores son las más importantes. Mientras que en el álbum familiar, es el proceso tecnológico el que ha condicionado esta característica. Sin embargo, en la actualidad, es una opción con la que el usuario cuenta; incluso se opta por los tonos sepias o modificar los colores originales de sus fotografías.

\section{La representación y la muerte en la fotografía}

La búsqueda permanente de la imagen, a lo largo de la historia, ha puesto de manifiesto dos aspectos: su ser simbólico, en su afán de procurarse representaciones; y el miedo humano a desaparecer o a dejar de existir. Al principio, fueron los autores de las pinturas rupestres los que buscaron reflejar las actividades cotidianas de la tribu; luego serían los pintores y después los fotógrafos dentro del escenario social y familiar. Debray (1992: 24) sostiene que "la 'verdadera vida' está en una imagen ficticia no en el cuerpo real. Las máscaras mortuorias de la Roma antigua tienen los ojos muy abiertos y las mejillas llenas [...] tienen posturas de resucitados, cuerpos gloriosos del Juicio Final en oración viva. Como si la piedra esculpida aspirara el aliento de los desaparecidos. Entre el representado y su representación hay una transferencia de alma. Esta no es una simple metáfora de piedra del desaparecido, sino una metonimia real, una prolongación sublimada pero todavía física de su carne. La imagen es el vivo de buena calidad, vitaminado, inoxidable. En definitiva fiable".

La imagen es vida permanente, contrapuesta a la muerte y a la ausencia. El álbum de fotos es objeto de vida festiva que cobra un halo sagrado, objeto de ritual que sólo tiene lugar entre cercanos y en medio de una atmósfera de intimidad, porque es de saber que el álbum puede carecer de especial significación ante la mirada desconocida, porque esta desconoce 
la historia que le otorga profundidad y sentido, aunque conserve siempre la esencia de su ser imagen, es decir, aquella capacidad de conmover simplemente por lo que en él se contemple: miradas, gestos, sonrisas, paisajes, sin importar quiénes son o qué lugares son; lo que a fin de cuentas despierta el studium, definido por Barthes.

Se considera a la fotografía como fuente de realismo que desborda, cuando acaso es más fuente de incertidumbre, tenue reflejo de la compleja realidad, porque de lo contrario ¿qué hay de las apariencias? La fotografía de un día soleado no siempre apunta a un día de estío; un rostro sonriente no siempre corresponde a un corazón feliz. La verdad mora escondida detrás de la apariencia de las cosas. Es más, gracias a ese sentido hay formas, representaciones y hay imagen, porque "sin un fondo invisible no hay forma visible" (Debray, 1994: 25), mas ese fondo invisible es la verdad oculta condicionada por la intencionalidad (recta o no) del fotógrafo, según busque revelar la verdad o construir una mentira. Aún cuando fuere su intención revelar la realidad, no conseguirá gran cosa, pues la forma visible suele ser siempre muy estrecha para un fondo invisible de común inabarcable.

La foto es incertidumbre e inquietud continua. Es señuelo que busca llevar más allá y son esas potencialidades suyas las que atraen al buen observador, porque lo empujan a buscar algo más que en ellas no se ve pero se presiente. La fotografía no es destino, es puente; no es mensaje, es canal, porque a través de ellas es posible rozar los umbrales de realidades desconocidas, inaccesibles y ocultas.

En la fotografía familiar, lo que se archiva es la realidad interior del sujeto, no tanto el patio, la cocina o la granja (realidades exteriores), sino la historia que a estos lugares acompaña y que cobra vida en la mente de sus protagonistas. El álbum es medio que destina a una vida eterna intangible, donde todos los ausentes danzan, lloran, ríen y sonríen al unísono y permanentemente.

\section{El álbum familiar como objeto y como experiencia grupal}

Sostiene Baudrillard (1969) que los objetos producen un cambio silencioso y significativo en los sujetos más allá de su funcionalidad. La experiencia fotográfica, que es el triunfo de la técnica sobre el dominio de la luz, adquiere corporalidad con la impresión de la imagen capturada en una pieza de cartón. Durante mucho tiempo, la fotografía podía ser tocada, palpada, asida entre las manos, poseída, ser colocada en los más íntimos aposentos; dentro de un cuadro, sobre una repisa o colgada de una pared. Sin embargo, a la par o más allá del portafotos, la fotografía ha tenido siempre por morada el álbum.

El término "álbum" proviene del latín album, forma neutra del adjetivo albus que significa "blanco" ( $c f$. Nueva Enciclopedia Sopena, 1955: 195). Los romanos usaron ese vocablo para denominar a la tabla blanca donde las autoridades escribían los mandatos para el pueblo. Lo importante de dicha acepción es su cercanía a la palabra blancura, la misma que no demora en remitir a la luz, así como al blanco del ojo, que según Armando Silva observa, en la práctica médica de países latinos se denominaba album oculi cels (ápud 
Bayardo y Lacarrieu, 1999: 185). Se podría afirmar que la imagen fotográfica cuenta con una doble naturaleza: la que se origina del haz de luz (que captura un fragmento de tiempo en sombras y siluetas); y la de su ser material, el mismo que va a reposar sobre la superficie albina de unas páginas encuadernadas para luego ser continuamente revisadas. Silva observa que "es significativo que albus, usado por célebres escritores latinos haciendo referencia a blancura, derivara hacia próspero y feliz, hasta el momento en el cual albo pasó a significar en Horacio: 'marcar un día como feliz"” (ibídem: 185).

El álbum, hasta no hace mucho tiempo, es la materialidad del legado familiar y su pasado ha sido común a cientos de familias desde el siglo XIX. Se diría que su naturaleza es cóncava, en tanto que contiene numerosas fotografías de condiciones diversas y que su función es la de un archivo donde las familias atesoran "lo que ha sido" para mostrarla a gente cercana. El álbum, como objeto-archivo, permanece dentro del espacio doméstico y resulta ser lo que un museo es en el espacio urbano: este que almacena objetos y aquel que almacena imágenes de "momentos-compartidos-en-familia". A este punto, resulta explícito que la funcionalidad del álbum está profundamente ligada a la memoria y a la identidad, ya que el álbum (marco de la experiencia grupal) inmortaliza fotográficamente la convivencia de un grupo al dar testimonio y quedar como memoria de unos estilos de vida que reafirman su identidad.

El porqué del álbum se remonta a las inquietudes del hombre prehistórico, la misma que instó al hombre de las cavernas a dejar en ellas el reflejo de sus faenas y de sus propios sueños. Esta inquietud de verse para identificarse y "autoconocerse" bien pudo haber quedado cubierta con ver sus reflejos sobre la superficie del agua; sin embargo, fueron los dibujos rupestres los que le permitieron colmar a plenitud esa necesidad y pervivir por siempre. Existe una doble inquietud entonces: la del autoconocimiento (tomar distancia de uno mismo) y la de buscar la propia permanencia como una necesidad de trascendencia; y a este menester ha sido de gran ayuda la fotografía como antídoto contra el olvido y la muerte.

En el álbum prevalece la experiencia de grupo, ya que la fotografía (en sus inicios, por sus limitaciones técnicas y de acceso) era una herramienta para resguardar los momentos especiales. También caben muchas fotos individuales y de retrato. Incluso, junto al álbum familiar, pervive también el álbum de cada individuo.

La temática común de las fotos de álbum gira en torno a la juventud y la belleza de la gente, de sus lugares conocidos y de sus momentos felices; de ahí que desde Horacio hasta ahora el álbum o la fotografía familiar estén profundamente asociados al "día feliz" o al "momento feliz"l.

No obstante, al ser parte el álbum de la organización de la vida, también se constituye

\footnotetext{
1. Resulta común durante las reuniones familiares la pose como parte de la celebración, en la que por breves segundos los celebrantes protagonistas se permiten estarse estáticos frente al flash de una cámara, cual ventana al futuro. ¿Qué necesidad se tiene de interrumpir los momentos alegres de movimiento y libre desplazamiento, con una quietud poco simulada?
} 
como ritual y queda ligado a sucesos gratos y a todo tipo de acontecimientos de la vida y de la muerte. Antes de la fotografía digital, la funcionalidad de las fotos apuntaba a ser partícipe de acontecimientos y no de la cotidianidad. En consecuencia, la fotografía (como testimonio) constituía el lugar tanto de los momentos alegres como de todos aquellos que hacen una vida; por lo que también devenía en tesoro: "cofre donde se depositan restos", perteneciente a la intimidad de la familia que busca compartirla con los más cercanos.

La fotografía (como parte de la vida cotidiana de la gente) adquirió mayor presencia en la medida en que se perfeccionaba y se simplificaba la técnica. A partir de ahí, se comienzan a registrar no sólo momentos de felicidad en familia, sino también eventos comunes de la vida diaria, aumentándose las temáticas individuales.

\section{Una familia en imágenes}

La familia de Teresa García de Barrantes (68 años) vive en el distrito de Surco (Lima, Perú). Desde los inicios de su vida matrimonial ha organizado las fotografías familiares en álbumes. La lógica de organización ha sido en función de los acontecimientos más importantes de su familia. En la entrevista mostró diecinueve álbumes. No obstante, comentó que conservaba otros más antiguos (de sus padres) y de cuando aún era soltera.

Uno de los aspectos importantes a destacar es la importancia del relato al momento de mostrar los álbumes, para entender el sentido y la importancia de cada uno de ellos y de cada foto al interior. Al comenzar, se le pidió a Teresa que eligiera el álbum. Decidió, entonces, comenzar por el álbum de su intercambio de aros (figura 1). "En el intercambio de aros yo tenía 22 años. Aquí en esta foto está mi madre. Yo no tengo papá, porque murió cuando yo tenía 12 años, pero mi mamá es quien nos sacó adelante. Acá también están mis hermanos. Éramos cinco” (García, 2014).

Figura 1: Intercambio de aros matrimoniales.

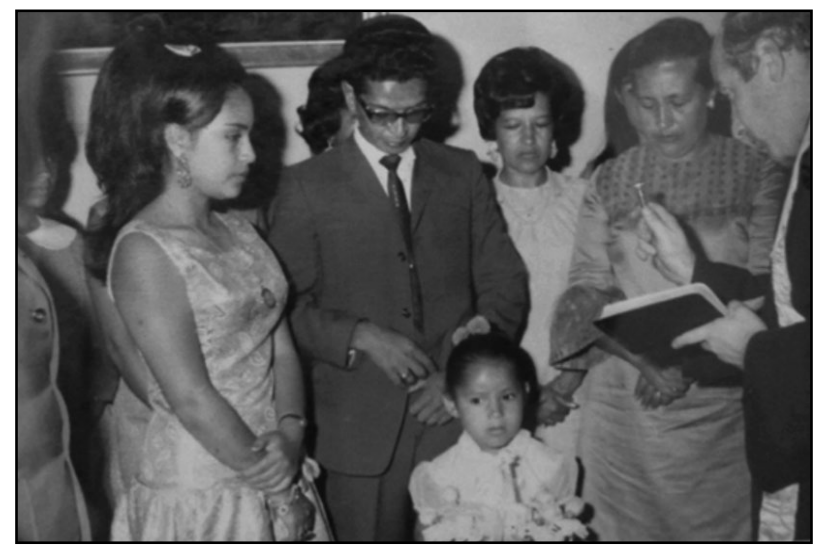

Fuente: Álbum de fotos de Teresa García. 
A medida que se avanzaba con la presentación, cada foto iba convirtiéndose en una ocasión para relatar la propia vida más allá de las mismas imágenes. "En esta foto están los hermanos Zañartu con Tito Barrantes, mi esposo (figura 2). Ellos son sus primos hermanos. Y aquí en esta foto del cambio de aros... están July, Nena, esta foto es del 70... En las fotos de mis bodas de plata, ya van a ver las fotos... también están. Incluso Antonio Zañartu cantó el Ave María en mis bodas de plata que fue en el Juan XXIII” (ibídem).

Figura 2: Ceremonia de bodas de plata.

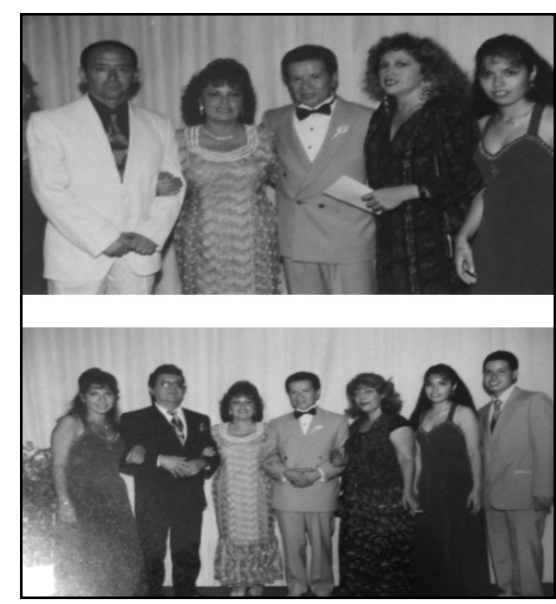

Fuente: Álbum de fotos de Teresa García.

Teresa y Tito son de Cajamarca. Se casaron en Lima en 1971 y sus hijos nacieron en esta ciudad. Se pudo contemplar que el orden de la estructura del archivo era de exclusiva autoría de Teresa, además que la memoria familiar correspondía a una sola generación: la suya, como madre y esposa.

Figura 3: Matrimonio civil.

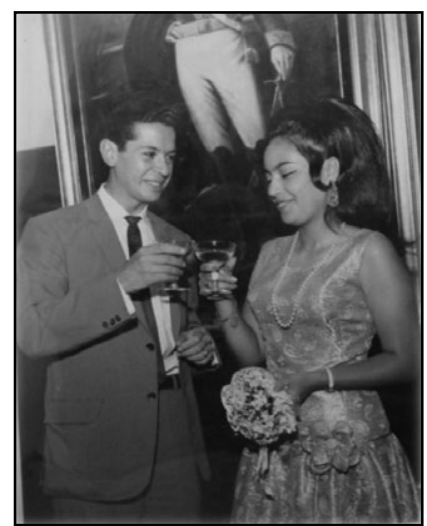

Fuente: Álbum de fotos de Teresa García. 
Lo asombroso, a medida que la muestra avanzaba, fue la cantidad de fotografías por álbumes correspondientes a cada uno de los acontecimientos vividos y según el siguiente orden: intercambio de aros, pedida de mano, matrimonio civil, matrimonio religioso y con la posterior organización de nuevos álbumes por cada uno de los nacimientos de sus tres hijos. "Estas fotos de acá corresponden al álbum del matrimonio civil, esto es en la Municipalidad de Jesús María (figura 3). Yo me casé un 4 de febrero civil y el religioso fue al día siguiente. Así era antes, el civil siempre era un día antes. Este es el alcalde de Jesús María, ahora delegan. Me casé en la Iglesia La Salle” (figura 4).

Figura 4: Matrimonio religioso.

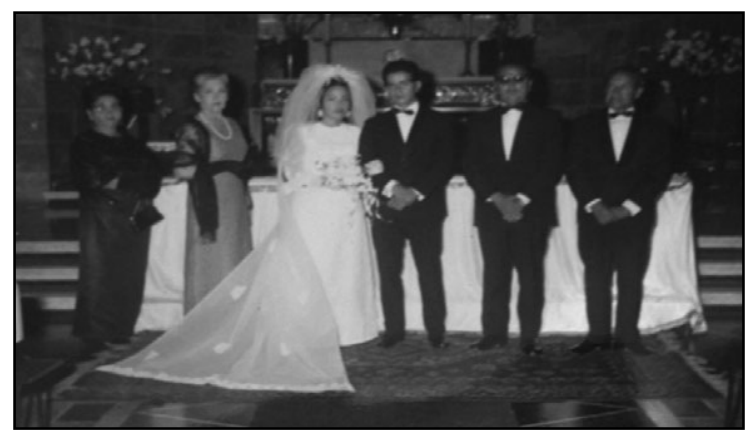

Fuente: Álbum de fotos de Teresa García.

Además de las fotografías de sus hijos recién nacidos, Teresa conservaba junto a los álbumes las pulseras que a sus bebés les habían puesto en el hospital apenas nacieron. Este gesto es constante en los casos analizados. Los álbumes son acompañados por estampas, partes, capillos y demás recuerdos que, junto al relato oral, complementan los documentos fotográficos. "Cuando mi niña Nardí tenía 2 años y 10 meses, nacieron mis mellizos. Ellos también tienen su álbum (figura 5). La música de moda en las fiestas infantiles era Yola. Las niñitas usaban sus medias cubanitas blancas y sus zapatos de charol negro".

Figura 5: Cumpleaños infantil.

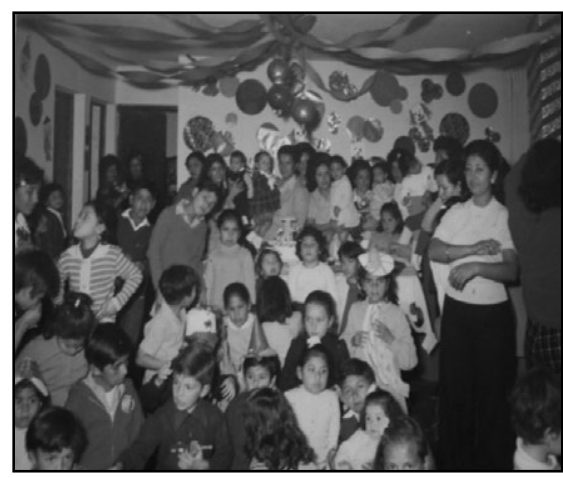

Fuente: Álbum de fotos de Teresa García. 
Una considerable parte de su colección de álbumes correspondían a los cumpleaños de cada uno de sus hijos. "Antes, las fiestas infantiles tenían payasos, magos, títeres. Yo siempre hacia la decoración de la casa en los cumpleaños y los dulces. En esa época no había tanta facilidad como hay ahora. Con mi esposo, para los cumpleaños de nuestros hijos, hacíamos las sorpresas con cuatro meses de anticipación". Un rasgo característico de la familia Barrantes que sin duda ha sido impulsado por la madre, es la celebración de todos los acontecimientos familiares e individuales más importantes en la vida de una persona, lo que se podría llamar "la celebración de la vida" que connota felicidad. Así, se tiene que esta familia ha celebrado los quinceañeros de sus dos hijas y los dieciocho años de su único hijo; así como conservan las fotografías correspondientes a la primera comunión, el bautizo, etc. (figura 6). La cuidada celebración de dichas celebraciones pone de manifiesto una premeditación orientada a la obtención de armonía, más allá del protagonismo que dichos acontecimientos pueden suponer.

Figura 6: Bautizo.

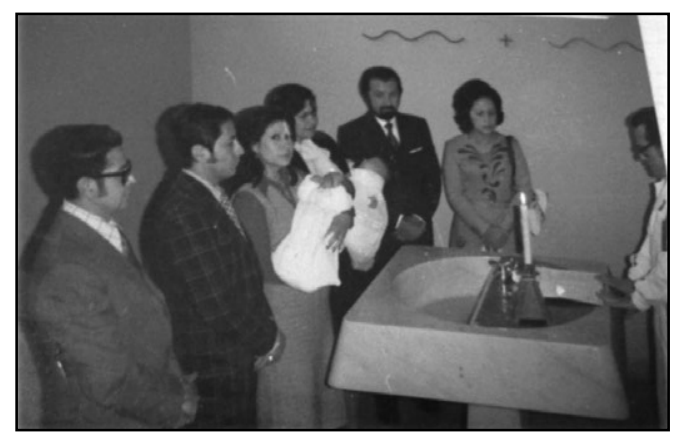

Fuente: Álbum de fotos de Teresa García.

La descripción e inmediata explicación de algunos detalles en las fotos (que expresan la moda o la costumbre de la época) afloraban de modo natural en la emotiva explicación de Teresa: "Antes, como pueden observar en las fotos, se acostumbraba usar los peinados en alto con unos rulitos que caen". Así es como los rasgos de una historia familiar y la de una época se entrelazan en las fotografías, las mismas que se convierten no sólo en documento histórico de la familia, sino de toda una época y de una cultura.

Teresa confiesa lo que significa para ella el álbum familiar: "Tiene una importancia grande porque pienso que los pasajes que el ser humano vive desde que nace y muere solamente los puede revivir a través de la fotografía, llámese digital o moderna, así como la que se recopila en los álbumes. Por lo general, se lo muestro a la familia para que recuerde las fechas o para ver cómo éramos de jóvenes, el look, la vestimenta. Básicamente, para recordar a los miembros de la familia, un determinado evento o momento. Tengo muchos álbumes, sólo estoy mostrándoles algunos. Tengo álbumes de mis sobrinos que ni mis hermanos tienen. Los tengo clasificados. A veces incluso me llaman para pedirme datos. El otro día mi hermano quería sacar una partida de bautizo de su hijo y me llamó para preguntarme la fecha en qué fue bautizado. Me dijo: 'como tú tienes tus álbumes y guardas 
todo, hasta los capillos, ayúdame con ese dato' y efectivamente revisé ese álbum y le proporcioné la información que necesitaba. También, como pueden observar, tengo fotos en portarretratos".

Una vez que mostró las fotos de su juventud destacó la importancia del arreglo personal antes de una sesión de fotos en otras épocas. "Antes la gente posaba y se arreglaba para la toma de fotografías. No es como ahora, que es en cualquier momento, como estés, no necesariamente por un evento en especial. Antes se guardaban los negativos, pero por la mudanza ya los deseché".

Teresa señala dos aspectos importantes que habrían desaparecido en la sociedad actual. Por un lado, la fotografía, convertida ahora en instrumento cotidiano que registra "instantáneas" efímeras que corren el riesgo de perder importancia con el paso del tiempo. Esto se contrasta con la práctica en décadas anteriores, cuando una fotografía cobraba el valor del evento en el que era registrada. Otro aspecto es la desaparición de los negativos: "Cuando mis familiares ven los álbumes, ellos reviven los momentos, gozan. Tengo pocas amigas que hacen álbumes, pero no con tanta intensidad como yo. En nuestras reuniones, todos los años tenemos un almuerzo el 30 de agosto, siempre me piden que lleve fotos y recordamos todas juntas diversos momentos".

A pesar de los cambios que la tecnología digital ha traído, Teresa sostiene que aún sigue organizando las fotografías con la ayuda de sus hijos y esposo. "Los álbumes los organizo por eventos. Tengo más fotos que videos. Tengo también un portarretrato digital y entran 500 fotos".

\section{Desplazamiento del álbum familiar al álbum digital}

El reemplazo del soporte físico por uno digital es un fenómeno propio de la era de la Internet. En el caso del álbum familiar, este cambio parte del uso de la cámara fotográfica digital. En la actualidad, el mercado ofrece una gran una variedad de cámaras digitales, las cuales aparecen relativamente desplazadas con las aplicaciones de los teléfonos inteligentes. En todo caso, el ingreso de esta nueva tecnología (portátil, ágil y sencilla) ha generado defensores y detractores.

Los fotógrafos tradicionales sugieren que esta revolución no ha sido beneficiosa para la fotografía: "La calidad obtenida no es la misma y que el proceso tradicional es superior" (Strizinec, 2006: 1). Esta postura es comprensible, ya que un cambio radical no es fácil de procesar y siempre genera resistencia. No obstante, para el usuario de hoy (quien no conoce plenamente las técnicas de revelado, ni de composición de la imagen ni la correcta iluminación) el formato digital se presenta como una forma más sencilla y divertida de registrar la realidad cotidiana. Warner (2012: 7) afirma que la fotografía es "la forma de arte que se ha visto más afectada por la revolución digital. El nexo entre las cámaras digitales, los teléfonos móviles con cámara, los ordenadores, los sitios web donde se pueden compartir fotografías y el software de posproducción ha creado más fotógrafos que en cualquier otra época de la historia". 
Camila Zevallos considera que "el rollo de película te obliga a pensar porque sabes que solo tienes 36 fotos y no vas a tener más" (ápud YouTube, 2014). Asimismo, Francisco Zevallos puntualiza: "Por más que estemos viviendo un cambio, una imagen no es una instantaneidad, detrás hay todo un proceso de edición. Quien ha sido formado en analógico entiende que hay una construcción de por medio, que la foto no termina en el hecho sino tienes una serie de posibilidades en el cuarto oscuro" (ibidem).

El soporte digital cubre las necesidades del fotógrafo amateur, quien generalmente recopila algunos momentos de sus vacaciones, reuniones familiares o amicales; e incluso imágenes propias en innumerables escenarios o simplemente en momentos de sosiego. Así pues, la concepción del álbum familiar (como fuente documental para reconstruir la historia de un pueblo o rememorar el pasado familiar) se ha visto alterada por la necesidad de crear una identidad virtual marcadamente individual y, con ella, la búsqueda de la aceptación de un determinado grupo.

En la sociedad contemporánea, se ha trastocado la sensibilidad y el significado que encierra un álbum familiar, así como la concepción de este como "memoria gráfica", de tal modo que poco se reflexiona sobre la importancia del álbum para la construcción de una identidad personal y colectiva.

Recogemos el testimonio de Eric Barrantes García (de 36 años, soltero, del distrito de Surco) y su experiencia con el formato fotográfico digital:

"Aquí tengo un álbum que le estoy haciendo a mi ahijado y cuando sea más grande se lo voy a mostrar. Uso Facebook, Twitter y recién he abierto Instagram, pero sobre todo por mi negocio. Instagram es una red social para compartir fotos, pero observo que no cualquier foto, sino de momentos especiales, quizá artístico; como por ejemplo, fotos de paisajes o de un viaje. Veo fotos muy trabajadas, muy bonitas hasta fotos de recomendación como el de un determinado plato en un restaurante.

En Facebook tengo varios álbumes de viajes, compromisos, etc. Ahora, en las reuniones o fiestas a las que voy, ya no llevo la cámara digital porque puedo tomar las fotografias con el celular. Además, sé que también habrá otros amigos que tomarán fotos y las van a compartir en Facebook. En cambio, para un viaje sí me preocupo de llevar la cámara y tomar fotos, porque resulta algo más personal, ya que de mí depende registrarlas y me gustará después difundirlas y compartirlas.

Alrededor de 2005 dejé usar la cámara de rollo y, a partir de entonces, usé la digital. Con la cámara tradicional tomaba una o dos fotos, pero con la digital tomo en cantidad. Antes tenía que tener en cuenta que el rollo era de 24 a 36 tomas, ahora es diferente. No tomo fotos todos los días, sólo en momentos especiales o también ante algo improvisado e inesperado, por ejemplo la llegada inesperada de un amigo. 
Una ventaja del álbum tradicional es que sencillamente lo sacas y muestras las fotos a tus amigos; en cambio, cuando las tienes en la computadora tienes que prender la computadora, esperar a que cargue y ubicar el archivo de fotos y si no los tienes en orden, resulta difícil. En cambio, en el álbum ya tienes todo clasificado, porque ya con anterioridad lo has ordenado: está listo para mostrar en cualquier momento. Recuerdo que antes del uso de las redes sociales uno enviaba las fotos al correo electrónico de un amigo o las quemabas en un disco y se lo dabas.

En mi computadora tengo mis álbumes ordenados por año. Sí me doy un tiempo para ordenarlas. Considero que es más emocionante ver una foto que solo contar determinado evento, a pesar que sean muchas fotos. Siempre, de una u otra manera, habrá oportunidad para ver todas las fotos que uno tenga. Tengo fotos de viajes, reuniones, salidas, de diversos motivos. A veces retoco las fotos, pero más arreglo la iluminación o corto cosas que no se ven bien. Lo hago con Photoshop y también con Infarview.

Elaboro álbumes digitales, pero siempre pienso en hacer álbumes en físico. Ahora con la cámara digital se toman tantas fotos, pero resulta costoso imprimir todas. Hay que hacer una selección y eso demanda tiempo. Imprimir también exige un costo. Es práctico tenerlo en la computadora, pero en particular yo sí quiero un álbum en físico" (Barrantes, 2014).

\subsection{Memoria, tiempo e identidad en la realidad globalizada}

Según Strizinec (2006: 2), la fotografía digital "es un paso más en la simplificación de los procesos posteriores a la toma fotográfica, pues elimina los procesos químicos largos y complicados para el usuario normal. Por su calidad actual, no es capaz de reemplazar equipos profesionales, pero si sigue con un ritmo de crecimiento tan rápido pronto lo hará a precios asequibles". En las circunstancias actuales, las fotografías ya no constituyen un álbum familiar (que origina la reunión de los miembros) sino un acto individualista. Si bien es cierto que pueden registrarse imágenes en grupo, esto no quiere decir que se fomente la reunión para hablar o comentar sobre estas como en épocas anteriores.

Los contenidos de las fotografías han cambiado y las posibilidades estéticas y técnicas son mayores. Con la interacción hombre-máquina, las fotos se obtienen al momento y, si se desea, con algunas modificaciones y mejoras. De aquella imagen (en la que no había forma de disminuir o quitar las imperfecciones físicas o propias de una carente iluminación) sólo queda el recuerdo. La posibilidad de poder retocar las imágenes en la computadora (e incluso en el teléfono móvil) hace posible que la fotografía no sea vista como la materialización de la memoria o la evocación del recuerdo, sino como una manera de buscar aceptación y (en algunos casos) de crear una identidad virtual que dista de la real. Dicha identidad se busca 
a través de las redes sociales, vitrinas de exhibición: en ellas, las fotografías constituyen un elemento importante para tal fin.

Los álbumes que aparecen en las redes sociales podrían ser calificados como productos de un "yoísmo" y no del deseo de registrar una historia, para luego ser descrita y narrada con ese sentimiento que sólo produce la añoranza, por todo tiempo pasado en el que se visitó o se disfrutó junto a personas que a lo mejor ya no están. Silva (2014: web) acota que "desde el nacimiento de las primeras redes sociales, pasando por el boom de Facebook e Instagram, hemos visto como la tendencia de automostrarse se ha incrementado. Y es que esta moda ya no sólo se reduce a las colegialas que se fotografían con su móvil en el baño del Instituto haciendo 'piquito' con los labios, sino que es una tendencia que se ha expandido en hombres y mujeres de cualquier edad".

Las personas que no poseen un retrato son vistas como si carecieran de una "historia" o una "identidad". Así, la colección de fotos narra icónicamente, mediante imágenes, una vida que busca constantemente la aprobación de los observadores u observators, como los llamaría Barthes, quienes aprueban o desaprueban (cual fisgones) las vistas con apenas voluntad para un studium, que Barthes (1989: 66) define como "el campo tan vasto del deseo indolente, del interés diverso, del gusto inconsecuente: me gusta/no me gusta, I like / I don't. El studium pertenece a la categoría del to like y no del to love; moviliza un deseo a medias; es el mismo tipo de interés vago, liso, irresponsable que se tiene por personas, espectáculos, vestidos o libros que encontramos "bien"”. De tal modo que la "aprobación" o "desaprobación" de dichas vistas puestas en exhibición momentánea no pasan de ser efímeras e insustanciales.

La calidad de una fotografía digital se mide en megapíxeles. A mayor cantidad de píxeles que forman una imagen, se asegura una mayor calidad. El número de píxeles ${ }^{2}$ indica la cantidad de información almacenada, pero no plasma la manera cómo el usuario interpreta cada imagen o qué utilidad le dará a dicha recopilación de momentos. Tampoco describe la nostalgia ni el sentimiento producido al ver determinada imagen ni mucho menos certifica la elaboración de un álbum familiar tradicional.

Las fotografías registran impresiones de la vida, momentos que se buscan recordar e inmortalizar. Por ese motivo, se procura recopilarlos y guardarlos para que, al cabo de los años, se pueda regresar a ellos, aunque sólo sea a través de una imagen. Este rol tradicional del archivo fotográfico se ha transformado en un desorganizado compendio digital de fotos saturadas de voces (como en el caso de Facebook) y comentarios. Barthes sugiere que "la imagen fotográfica embalsama una porción de tiempo pero también una imagen de vida detenida, la cual al final, con el paso real del tiempo, se convertirá en una imagen de la vida

\footnotetext{
2. Warner (2012: 205) califica a los píxeles como "minúsculas unidades de información visual”, que han hecho posible "editar y transmitir fotografías utilizando programas de ordenador e Internet, y han eliminado las técnicas manuales y en tiempo real que se empleaban en el laboratorio. En la actualidad, las herramientas elementales de edición de imágenes están ampliamente disponibles para uso de los aficionados".
} 
después de la muerte" (ápud Green, 2007: 126). Se desconoce cómo arribarán al futuro las porciones de tiempo embalsamadas en la actualidad, mediante la cámara digital y en los archivos virtuales.

No obstante y pese a su transformación, el álbum familiar pervive en la dimensión virtual, aún cuando ha dejado de ser predominante el principio del grupo y de la familia. Un álbum requiere de tres elementos: a) la familia, que viene a ser el sujeto representado; b) la foto, el medio visual del registro; y c) el álbum, la técnica de archivo. De estos elementos el que varía es el último: se pueden tener álbumes ordenados de manera lógica o uno donde las fotos son sólo pegadas para tener un sitio donde guardarlas, sin que las fotografías tengan relación entre ellas (cualidad frecuente en el sistema digital). Antes se daba el caso de almacenar las fotos en cajas, sin ningún orden preestablecido, dado que el único fin era salvaguardarlas. En la actualidad, el equivalente a esas cajas de archivo son las "carpetas" en la computadora.

Un álbum familiar permanece como un archivo de imágenes que documenta el pasado histórico de las familias, reforzando el sentimiento de permanencia. Ante la muerte y el olvido, se constituía en herencia y memoria. No obstante, en la actualidad, el fin práctico del álbum digital es el de reafirmar una identidad que se exhibe y se somete voluntariamente a la aprobación o desaprobación de los observadores.

Así pues, la Internet y las nuevas tecnologías hacen posibles nuevas formas de archivar el pasado familiar y personal, a través de la imagen fotográfica digital, lo que ha suscitado una nueva forma de percibir y narrar el pasado; construir la memoria y la identidad. Las redes sociales se constituyen en nuevos depositarios o soportes de las imágenes de vida que cada persona no sólo reserva, sino exhibe en Internet como parte de la narración de su pasado inmediato: hábito que pone en evidencia los nuevos imaginarios de la gente en torno al tiempo y a su concepción de la vida. De esta forma, existen claras diferencias entre los modos de archivar y recordar con las fotografías familiares de los álbumes y con los archivos digitales. El álbum en las redes sociales es un archivo de fotografías que gira en torno a una persona y ya no a una familia.

La cámara fotográfica digital, integrada a los celulares, se ha adherido poderosamente a los diversos estilos de vida de las personas y se ha hecho parte de su cotidianidad y sus circunstancias. Así pues, la fotografía es medio de comunicación permanente entre los individuos que, a su vez, es complementado con el discurso oral entre ellos. La foto se constituye en instrumento que ayuda a la memoria a recordar personajes, escenarios, situaciones y eventos ahora no tan pasados. Para Andrés Longhi, la fotografía "se ha democratizado" (YouTube, 2014). Francisco Zevallos afirma que las fotos engloban un "lenguaje de carácter universal que estábamos buscando los seres humanos". A su turno, Camila Zevallos puntualiza que "es la manera de ver la vida ahora” (ibídem).

Así como se comparten mensajes instantáneos (acompañados de imágenes) a través de los smartphones, las redes sociales en Internet han reemplazado a los álbumes fotográficos de antaño. "En 2011, Flickr, el sitio web donde se pueden publicar fotografías, tenía más de 
6.000 millones de imágenes procedentes de una amplia variedad de fuentes, que van desde particulares a Instituciones como la Biblioteca del Congreso de Estados Unidos, que utiliza el sitio web para facilitar el acceso a colecciones que de otro modo raramente se verían" (Warner, 2012: 86).

En la era digital, compartir fotografías o exhibirlas de manera online ha hecho que los revelados se den con menos frecuencia. "Las imágenes registradas pasan de usuario a usuario y por lo general no se muestra la intención que estas tomen forma material. Más que las cámaras digitales, los teléfonos móviles con cámara son los que han desmaterializado la fotografía, transformándola de un objeto físico tangible a una imagen retro iluminada efímera, que es improbable que se imprima. Debido al hecho de que los usuarios tienden a llevarlo consigo o a tenerlo siempre cerca, el teléfono está más disponible que incluso la cámara digital para las instantáneas tomadas al vuelo, fotografías sin premeditación y rápidas que se han asociado desde hace tiempo a la fotografía de calle" (ibídem: 191).

Marinello (2005: 13) considera que "las herramientas de un oficio pueden cambiar, pero el espíritu que las anima persiste, pues la fotografía más que asunto de cámaras y técnicas, intentar ver con el corazón". En concordancia con el autor, la fotografía y su recopilación tienen un valor sentimental indescriptible y enriquecedor, aún cuando las motivaciones no sean las de antes. La fotografía digital ha simplificado los procesos: "Durante más de siglo y medio, la fotografía ha sido 'el arte de escribir con luz' y ha desarrollado un lenguaje propio y subjetivo que dista mucho de la concepción de 'registro mecánico' que injustamente se le ha colgado en muchas ocasiones. Lo digital es, sin lugar a duda, un importante y significativo cambio en las herramientas. Estos nuevos artilugios proveen de más posibilidades que todas las anteriores, pero no modifican en absoluto los lenguajes propios que la fotografía ha desarrollado por más de siglo y medio" (ibídem: 164).

En un mundo globalizado, la identidad se construye de modo diferente con el uso de innumerables maniobras y montajes realizados. Así, estamos en presencia de un escenario en donde el registro original se esfuma y se da pase a ciertos retoques o transformaciones (con el empleo de filtros) para mejorar la apariencia de la toma efectuada.

Asimismo, el registro de fotos (sin un motivo especial) es un rasgo característico de los usos de la fotografía actual. Antes, las imágenes eran captadas en una fecha, lugar o acontecimiento especiales, mientras que ahora las fotografías son hechas (y difundidas) en cualquier momento. Todo parece indicar que la tendencia no sólo es la de conservar, sino de exhibir rasgos de una vida social supuestamente activa o interesante, que a su vez insinúe cierto estatus o nivel de bienestar alcanzado, fines que hallan el escenario adecuado en las redes sociales. La última moda es la de autofotografiarse, el selfie, que tuve efecto masivo a raíz de la realizada por la presentadora de televisión, Ellen DeGeneres, junto a once celebridades durante la $86^{\circ}$ edición de los premios Óscar (El Comercio, 2014).

La obtención de un selfie radica en el interés de una persona por autorretratarse, sosteniendo un móvil o una cámara. Suele apuntarse a sí mismo (la mayoría de los smartphones poseen un lente frontal) o frente a un espejo. La foto resultante es comúnmente difundida 
en las redes sociales. Muchos psicólogos y sociólogos catalogan al "selfismo" como una patología asociada al narcisismo, al exhibicionismo o, en su contrario, la autoestima baja (Silva, 2014). Esta modalidad sería una muestra concreta de la preponderancia del "yo" y la individualidad en el uso de las imágenes a través de las redes.

La significación de las fotografías familiares o personales (expuestas en Internet) varía según la intencionalidad de los operadores y de la valoración de los observadores. Tagg (2005: 241) observa que la imagen "debe verse como un compuesto de signos, que debe compararse más con una frase compleja que con una palabra individual. Sus significados son múltiples, concretos y, lo que es más importante, construidos”. Por su parte, John Szarkowski considera que la fotografía "es el medio más capaz de captar un sinfín de impresiones de distintos significados posibles, el medio más capaz de explorar libremente, sin fórmulas, las verdaderas caleidoscópicas de aspecto significativo" (ápud Badger, 2009: 12).

En consecuencia, se puede concluir que la importancia de la fotografía y del álbum radica en la preservación del pasado (trascender la muerte y conservar la memoria), así como la poderosa necesidad individual de autoafirmación en un mundo donde, gracias a la democratización de los medios a través de Internet, todos pueden ser protagonistas y en el que la fotografía establece un diálogo fluido y permanente entre el mundo y cada individuo.

Sin embargo, este cambio tecnológico ha implicado una pérdida significativa, sobre todo en los procedimientos de preservación de los recuerdos. Según Óscar Chambi (2014), en las generaciones jóvenes "hay pérdida de lo romántico, de buscar un archivo y de comprometerse a elaborarlo. En un instituto de arte les pedí, para una práctica, que busquen la foto más antigua de sus familias; y me trajeron daguerrotipos, fotos antiguas, etc. Un estudiante de familia de emigrantes italianos me trajo un álbum fabuloso; algunos álbumes más bien maltrechos; otros, fotos sueltas. Les dije que los conserven. Ese trabajo me encantó y se me ocurrió hacer un libro sobre la migración japonesa en el Perú, titulado La memoria del ojo". Así pues, el archivo fotográfico familiar trasciende y se convierte en un archivo histórico social de una determinada y lugar.

\subsection{Los recursos digitales}

La Internet y las nuevas tecnologías de la comunicación han hecho posible contar con herramientas de edición y almacenamiento de imágenes. Una de las aplicaciones gratuitas más utilizada entre jóvenes y adultos es Instagram. Esta aplicación permite tomar fotografías con efectos especiales y compartirlas en redes sociales como Facebook, Flickr y Twitter. Cabe destacar que Instagram posee filtros digitales que permite mejorar la calidad de la imagen y modificar los colores, ambientes, bordes y tonos ${ }^{3}$.

3. Miguel Ángel Fernández (2014) acota que "Instagram te da la opción de poner filtros a las imágenes así como Photoshop. Se puede poner filtro sepia, blanco o negro o el que se decida. Las fotos pueden ser vistas por tu círculo de amigos o se puede configurar la privacidad". Veliz (2013) comenta sobre esta aplicación: "Instagram añadió la posibilidad de compartir video desde su plataforma. Esta herramienta, disponible de manera oficial en 
Lo que caracteriza a esta aplicación es que el contorno es cuadrado y redondeado hacia las puntas en las fotografías, en honor a la Kodak instantánea y a las cámaras Polaroid. Esta aplicación (con la que se puede tomar una foto o elegir una imagen registrada que se tiene en el teléfono inteligente, para después ajustar la imagen del tamaño de un cuadro, como en las fotografías de antaño y aplicarle un filtro para darle un efecto vintage) tiene sus seguidores y sus críticos. "Hay quienes consideran que sólo se trata de un espacio que glorifica fotos mal tomadas de ocasos aburridos y miles de gatos. Sus críticos aseguran que si la gente realmente quiere apostar por lo vintage deberían tomar fotos normales, almacenarlas y después volver a verlas cinco años después” (Cuen, 2012).

Entre sus seguidores se encuentran generalmente jóvenes ${ }^{4}$ y representantes del mundo de la moda. Phil Gonzales explica que "con Instagram consigues separarte de los atributos físicos del producto y te acercas más al marketing de 'engagement' (implicación), sitúas a tu marca donde quieres que esté y la vinculas a sensaciones e ideas de una forma muy potente" (ápud Carrión, 2011).

Hoy en día, la fotografía (pura y natural) es transformada y modificada por alguna aplicación o programa que mejora aspectos no deseados. Uno de esos programas es Photoshop. Badger (2009) sostiene que "en la era del Photoshop, el viejo dicho de 'la cámara nunca miente' parece haber sido reemplazado por el de 'la cámara siempre miente'”. Así pues, las imágenes que antes se solían almacenar en un álbum familiar hoy son expuestas y difundidas bajo la óptica de todo el mundo, pero con cierta técnica, el gran porcentaje de estas son retocadas. Antes el discurso era entre nosotros y nuestro entorno; en el presente es la exposición entre nosotros y el mundo, sin importar (en la mayoría de los casos) el momento y la acción. Lo que se consideraba una memoria visual (un recuerdo que conlleva a emociones, la inmortalización de eventos especiales) hoy es una manera de plasmar lo que se hace día a día, sea trascendental o no.

Con la era digital se ha perdido el misterio que imperaba antes del momento del revelado de la película. Ahora, se pueden capturar innumerables imágenes. Incluso se comparte y retoca (de manera instantánea) las fotografías gracias a las aplicaciones de los dispositivos móviles. Al parecer, la tecnología repotencia (en algunos casos) el reino de la mentira. Para Francisco Zevallos, "el ser humano es adicto a la belleza y a buscar la perfección de la belleza" (YouTube,

iOS y Android, incorpora filtros para la producción de un video de hasta 15 segundos de duración. Luego de la publicación de este formato, millones de personas producen contenido a diario y consumen este formato desde la web y dispositivos móviles. Una de las posibilidades que ha añadido la red social de fotografía a su sistema web, es la posibilidad de incrustar en un blog o espacio web".

4. Instagram es una herramienta que goza de bastante aceptación por los adolescentes y jóvenes. Así tenemos a Cristina Lara (2014) quien a la fecha tiene 92 fotos en Instagram y usa esta aplicación desde hace dos años. La adolescente de 17 años comenta: "En Instagram coloco fotos mías, de mis amigos o cosas curiosas que observo. También puedo etiquetar a los que están dentro de mi comunidad y poner ubicación. Publico de vez en cuando. Esta aplicación te pone retos como por ejemplo: 'Pon la foto del día durante un mes' [...] Me gustan registrar fotografías. Las archivo en la computadora, en el celular y hago tomas sobre la cotidianidad, no necesariamente sobre eventos especiales". 
2014). Según Andrés Longhi, "uno tiene que ser fiel a sus recuerdos. Si eres fiel a tus recuerdos es imposible mentir. Si se utiliza la tecnología para mentir, para poner bonitos tus recuerdos, estás siendo infiel contigo mismo. Creo que estamos entrando a un umbral de nuevos paradigmas en cuanto a comunicación, en cuanto a una serie de variadas situaciones" (ibídem).

En la era digital, quien toma la fotografía controla el proceso creativo: desde la selección de la realidad hasta la imagen o producto final. La transición del álbum familiar a la reinvención digital ha constituido un cambio no sólo en el instrumento, sino en la mentalidad y en la manera de realizar y almacenar las fotografías.

\section{Conclusiones}

En la actualidad, la cámara fotográfica es un instrumento usado para registrar la cotidianidad y no necesariamente eventos felices de la vida. No obstante, el álbum familiar persiste, sea como tesoro o elemento histórico de un grupo familiar, con especial significación entre las personas mayores. Las generaciones jóvenes son más "inmediatistas": no piensan en el pasado y su concepto de "archivo" es mucho más volátil y pasajero. Empero, todo parece indicar que los archivos digitales (en las computadoras y en las redes sociales) son una nueva forma de revivir los recuerdos y de preservar el pasado.

Gracias a la Internet, a la cámara digital y al teléfono inteligente, el concepto de "representación del yo" ha adquirido un nuevo significado. En la mayoría de los registros de imágenes (que se pueden observar a través de las redes sociales) predomina el sujeto como eje central. La valoración del momento, el lugar y el entorno ha pasado a un segundo plano. Ahora, la creación y composición de la imagen surge por espontaneidad y, en ese sentido, ya no es potestad del fotógrafo profesional realizar las fotografías: esta acción queda a merced del ciudadano en general. Asimismo, el retoque digital hace posible poseer rostros y cuerpos "perfectos"; los paisajes pueden ser modificados.

La fotografía representa un recuerdo y evoca a la nostalgia; permite al observador transportarse a un espacio y tiempo determinado. Constituye un elemento vital para la identidad personal, familiar y nacional. La recopilación de imágenes en un álbum familiar es trascendental para conocer nuestra historia, gustos y creencias, como miembros de una familia y de un país.

\section{Fuentes consultadas}

Álvarez-Dardet, A. (2013, agosto 28). "Joan Fontcuberta: 'Los álbumes han sido sustituidos por las redes sociales"”. Extraída el 2/VII/2014 desde http://cultura.elpais.com/ cultura/2013/08/28/actualidad/1377705343_852989.html

Badger, G. (2009). La genialidad de la fotografía. Cómo la fotografía ha cambiado nuestras vidas. Barcelona: Blume. 
Barrantes, E. (2014, mayo 26). Entrevista personal. Lima.

Barthes, R. (1989). La cámara lúcida. Barcelona: Paidós.

Baudrillard, J. (1969). El sistema de los objetos. México D. F.: Siglo XXI.

Bayardo, R. y Lacarrieu, M. (comps.). (1999). La dinámica global/local. Buenos Aires: La Crujía, Ediciones CICCUS.

Carrión, P. (2011, octubre 19). "Por qué Instagram está revolucionando el mundo de la moda". Extraída el 1/VI/2014 desde http://smoda.elpais.com/articulos/por-que-instagrampuede-ser-la-nueva-big-thing-de-la-moda/241

Chambi, O. (2014, junio 25). Entrevista personal. Lima.

Cuen, D. (2012, abril 4). “¿Qué se esconde detrás de Instagram?”. Extraída el 2/VII/2014 desde http://www.bbc.co.uk/blogs/legacy/mundo/un_mundo_feliz/2012/04/que_se_esconde_detras_ de_insta.html

Debray, R. (1994). Vida y muerte de la imagen. Barcelona: Paidós.

El Comercio (2014, marzo 3). “Ellen DeGeneres y el 'mejor selfie de la historia' en los Óscar”. Extraída el 2/VII/2014 desde http:/elcomercio.pe/tvmas/hollywood/ellendegeneres-y-mejor-selfie-historia-oscar-noticia-1713309

El País (2013, agosto 28). “Joan Fontcuberta: 'Los álbumes han sido sustituidos por las redes sociales"”. Extraída el 30/V/2014 desde http://cultura.elpais.com/cultura/2013/08/28/ actualidad/1377705343_852989.html

Fernández, M. (2014, mayo 30). Entrevista personal. Lima.

García, T. (2014, mayo 26). Entrevista personal. Lima.

Green, D. (2007). ¿Qué ha sido de la fotografía? Barcelona: Gustavo Gili.

Lara, C. (2014, mayo 26). Entrevista personal. Lima.

Marinello, J. (2005). Técnica y lenguaje. Fundamentos prácticos de fotografía digital. Santiago de Chile: Universidad Católica de Chile.

Martín-Barbero, J. (1989). Procesos de comunicación y matrices de cultura. México D. F.: Gustavo Gili.

Morales, D. (2003). Lectura interpretativa de Walter Benjamin y Marshall McLuhan en torno al tema de la imagen fija y la fotografía. Bogotá: Universidad Externado de Colombia. 
Nueva Enciclopedia Sopena (1955). Diccionario ilustrado de la lengua española. Tomo I. Barcelona: Editorial Ramón Sopena.

Silva, J. (2014, enero 30). "Narcisismo digital: el 'selfismo' en la red”. Extraída el 6/ VI/2014 desde http://somosnovedad.com/narcisismo-digital-el-selfismo-en-la-red/

Sontag, S. (2006). Sobre la fotografía. México D. F.: Santillana.

Strizinec, G. (2006). Fotografia digital. México D. F.: Alfaomega.

Tagg, J. (2005). El peso de la representación. Barcelona: Gustavo Gili.

Veliz, J. (2013, septiembre 9). “TIP: Incrustar videos de Instagram en tu blog”. El Blog de Jesús Veliz. Extraída el 2/VII/2014 desde http://jevedel.blogspot.com/2013/09/tipincrustar-videos-de-instagram-en-tu.html

Vidal, J. (2001, junio 13). "Joan Fontcuberta: 'Hemos de hablar de la muerte de la fotografía"”. Extraída el 20/III/2014 desde http:/www.elcultural.es/version_papel/ ARTE/196/Joan_Fontcuberta_Hemos_de_hablar_de_la_muerte_de_la_fotografia

Warner, M. (2012). 100 ideas que cambiaron la fotografía. Barcelona: Blume.

YouTube (2014, mayo 12). "Qué ha pasado con la fotografía? Extraída el 14/V/2014 desde https://www.youtube.com/watch?v=Lm8NE9F7GSw 